\title{
PENANAMAN NILAI-NILAI KEAGAMAAN SISWA SDIT KH. ABDURAHMAN MAHMUD CIREBON
}

\author{
Rodiatul Maghfiroh \\ STIT Buntet Pesantren Cirebon \\ rodiatulmaghfiroh@gmail.com
}

\begin{abstract}
Education is said to be successful if education is able to turn students into human beings who have qualified knowledge and skills. However, knowledge and skills alone are insufficient. Because besides that, students must have a religious attitude so that they can display good moral and moral behavior in their daily lives. Humans are only smart but do not have good morals so he will do the actions in accordance with his wishes, even though it harms others. On this occasion, the author will discuss about how to instill religious values in SDIT KH.Abdurahman Mahmud students. This research is qualitative in nature, namely describing the results of research with the description of words not with numbers. The inculcation of students' religious values is carried out by: (1) Mauizhoh Hasanah (Advice), (2) Uswatun Hasanah (Exemplary), (3) Attu'udiyyah (Habituation), (4) Mulahadzoh Muhasyafah (Oversight/Intensive Attention) and (5) Ats Tsawaab wa al-'Iqaab (Reward and Punishment).
\end{abstract}

Keywords: Method of Internalization, religious values

\begin{abstract}
Abstrak
Pendidikan dikatakan berhasil apabila pendidikan itu mampu mewujudkan peserta didiknya menjadi manusia yang mempunyai pengetahuan dan keterampilan mumpuni. Akan tetapi, pengetahuan dan keterampilan saja yang dimiliki kurang cukup. Karena disamping itu, peserta didik harus memiliki sikap religius sehingga dapat menampilkan perilaku akhlak dan moral yang terpuji dalam kehidupan sehari hari. Manusia yang hanya pintar tapi tidak memiliki akhlak yang baik maka dia akan melakukan perbuatan yang sesuai dengan keinginannya saja, meskipun merugikan orang lain. Pada kesempatan kali ini, penulis akan membahas tentang bagaimana penanaman nilai-nilai keagamaan pada siswa SDIT KH.Abdurahman Mahmud dilakukan. Penelitian ini bersifat kualitatif, yaitu memaparkan hasil penelitian dengan deskripsi kata-kata bukan dengan angka-angka. Adapun penanaman nilai-nilai keagamaan siswa yang dilaksanakan yaitu dengan: (1) Mauizhoh Hasanah (Nasehat), (2) Uswatun Hasanah (Keteladanan), (3) Attu'udiyyah (Pembiasaan), (4) Mulahadzoh Muhasyafah (Pengawasan/Perhatian intensif), dan (5) Ats Tsawaab wa al-'Iqaab (Penghargaan dan Hukuman).
\end{abstract}

Keywords: Metode, penanaman, nilai nilai keagamaan.

\section{Pendahuluan}

Agama merupakan pedoman dan wahyu Tuhan yang diturunkan agar manusia hidup teratur, damai sejahtera, dan bahagia baik di dunia maupun di akhirat. Eksistensi agama merupakan kebutuhan primer bagi seluruh umat manusia di dunia ini. Karena kedudukan agama bersifat primer maka agama harus ditanamkan sejak dini kepada anak atau peserta didik. Menanamkan nilai-nilai agama kepada anak adalah tugas para orang tua selaku guru 
pertama dan utama di rumah dan keluarga, juga merupakan tugas guru di sekolah. Orang tua dan guru harus berkolaborasi dengan baik dalam menanamkan nilai-nilai agama pada anak.

Untuk memulai penanaman nilainilai agama di lembaga formal dimulai dari Sekolah Dasar. Sekolah dasar merupakan lembaga pendidikan yang pertama, yang keberadaannya sangat strategis untuk menumbuhkan religius kepada anak-anak, agar mereka menjadi orang-orang yang kuat, terbiasa dan mampu melaksanakan segala aturan agama yang diajarkan kepadanya. Tentunya dengan penanaman nilai-nilai agama sejak dini kepada anak, mereka akan mempunyai pondasi kokoh dalam beragama. Hal ini merupakan awal yang baik bagi pendidikan anak-anak untuk menjalani jenjang pendidikan selanjutnya.

Untuk menumbuhkembangkan nilai-nilai keagamaan pada peserta didik, diperlukan berbagai macam metode dan pendekatan. Pendekatan yang dimaksud adalah cara yang teratur yang digunakan untuk melaksanakan suatu kegiatan agar tercapai hasil yang baik seperti dikehendaki (Badudu Zain, 1996). Pendekatan juga berfungsi sebagai alat untuk mencapai tujuan. Guru di Sekolah Dasar yang dalam kegiatannya memerlukan berbagai metode dan pendekatan untuk mengembangkan berbagai kemampuan dan potensi yang ada pada diri peserta didik. Untuk itu, guru Sekolah Dasar dituntut memiliki kemampuan profesional dan komprehensif terutama dalam memilih dan menentukan metode dan pendekatan yang efektif. Dimana nantinya dalam proses belajar mengajar akan berlangsung dengan baik dan kondusif sesuai tujuan pembelajaran.

Pada kenyataannya, peserta didik belum mampu menunjukkan sikap religius dalam kehidupan sehari-harinya. Seperti yang penulis saksikan ketika peserta didik diajarkan "Bahwa shalat lima waktu itu wajib dan dianjurkan dengan berjama'ah tapi keadaannya tidak demikian peserta didik masih banyak yang meninggalkan shalat bahkan enggan untuk pergi ke masjid untuk berjamaah. Kasus lain ketika pendidik (guru) mengajarkan untuk berkata jujur dalam kehidupan sehari-harinya, akan tetapi tidak sedikit dari mereka yang masih berkata dusta, pandai untuk membohongi guru/pendidik dan orang tuanya. Hal tersebut dikarenakan belum maksimalnya transfer pengetahuan agama dan bagaimana mengaplikaskiannya dalam kehidupan. Untuk menginginkan agar peserta didik mampu mengaplikasikan nilai-nilai agama, maka seorang pendidik harus bisa mengajarkan nilai-nilai keagamaan dengan baik dan memberikan contoh dalam kehidupan sehari-hari.

\section{Penanaman Nilai-Nilai Keagamaan}

Penanaman menurut Kamus Besar Bahasa Indonesia artinya proses, cara, perbuatan menanam, menanami atau menanamkan (Depdiknas KBBI, 2008: 1392).

Nilai adalah kadar, mutu, sifat (halhal) yang penting atau berguna bagi kemanusiaan (W.J.S Poerwadarminta, 1982: 677). Nilai dalam pandangan Zakiyah Daradjat (1984:260) adalah suatu perangkat keyakinan ataupun perasaan yang diyakini sebagai suatu identitas yang memberikan corak yang khusus kepada pola pemikiran, perasaan, keterikatan, maupun perilaku.

Sedangkan Nilai menurut Said Agil adalah tolak ukur tindakan dan perilaku manusia dalam berbagai aspek kehidupan (Said Agil Al-Munawar, 2005: 4). 
Penanaman nilai-nilai keagamaan adalah meletakkan dasar-dasar keimanan, kepribadian, budi pekerti yang terpuji dan kebiasaan ibadah yang sesuai kemampuan anak sehingga menjadi motivasi bagi anak untuk bertingkah laku.

Penanaman nilai-nilai keagamaan yakni agama Islam yang penulis maksud di sini adalah suatu tindakan atau cara untuk menanamkan pengetahuan yang berharga berupa nilai keimanan, ibadah dan akhlak yang berlandaskan pada wahyu Allah SWT dengan tujuan agar anak mampu mengamalkan pengetahuannya dalam kehidupan sehari-hari dengan baik dan benar dengan kesadaran tanpa paksaan.

Adapun tujuan penanaman nilainilai agama Islam ialah untuk meningkatkan keimanan, penghayatan, dan pengamalan peserta tentang agama Islam, sehingga menjadi manusia muslim yang beriman dan bertaqwa kepada Allah SWT serta berakhlakul mulia dalam kehidupan pribadi, bermasyarakat, berbangsa dan bernegara (Muhaimin, 2008: 78).

\section{Metode penanaman nilai-nilai keagamaan}

Metode adalah suatu cara atau jalan yang harus dilalui untuk mencapai tujuan tertentu (Binti Maemunah, 2009: 56). Metode merupakan cara atau langkahlangkah guna mencapai tujuan yang diinginkan. Untuk itu, dalam pelaksanaan penanaman nilai-nilai pada anak maka harus dengan metode yang tepat. Penanaman diartikan sebagai cara/proses atau suatu kegiatan atau perbuatan menanamkan sesuatu pada tempat yang semestinya (dalam hal ini mengenai niainilai agama Islam yang berupa nilai keimanan, nilai ibadah dan nilai akhlak pada diri seseorang agar terbentuk pribadi muslim yang Islami) (Pusat Pembinaan dan
Pengembangan Bahasa, 1998: 890). Metode penanaman nilai-nilai agama Islam merupakan cara yang digunakan oleh guru untuk menyampaikan materi keagamaan kepada peserta didik agar nilai-nilai agama Islam melekat dan mendasari setiap perilakunya.

Ada beberapa metode yang dapat digunakan dalam proses pendidikan diantaranya menurut Abdullah Nashih Ulwan; (1) Metode Keteladanan (2) Metode Pembiasaan (3) Metode Nasehat (4) Metode Perhatian/pengawasan (5). Metode Hukuman (2007: 141). Sedangkan menurut Ahmad Tafsir (1) Memberikan contoh (2) Membiasakan tentunya dengan hal yang baik (3) Menegakkan disiplin (4) Memberikan motivasi atau dorongan (5) Memberikan hadiah terutama psikologis (6) Menghukum (7) Menciptakan suasana yang berpengaruh bagi pertumbuhan positif (2008: 64).

\section{Metode}

Pendekatan yang digunakan pada penelitian ini adalah model penelitian lapangan (field research) yang bersifat empirik pengalaman di lokasi penelitian.

Penelitian ini menggunakan metode kualitatif dimana penelitian ini menggunakan data deskripstif berupa katakata tertulis atau lisan dari orang-orang dan perilaku yang dapat diamati (Bogdan dan Taylor, 1975:5). Penelitian kualitatif dapat didefinisi bahwa hal itu merupakan penelitian yang menggunakan cara wawancara terbuka untuk menelaah dan memahami sikap, pandangan, perasaan dan perilaku seorang atau sekelompok orang.

Definisi di atas dapat disimpulkan bahwa penelitian kualitatif adalah bermaksud untuk memahami fenomena apa yang dialami oleh subyek penelitian 
misalnya tingkah perilaku, pandangan, motivasi, tindakan dan lain-lain dengan cara deskripsi, pada suatu konteks khusus yang alamiah dengan memanfaatkan berbagai metode ilmiah.

Penelitian kualitatif ini dengan tipe eksplorasi dan menggunakan metode analisis penerimaan atau reception analysis yang bertujuan untuk mengetahui penanaman nilai-nilai keagamaan peserta didik SDIT KH. Abdurrahman Mahmud.

Tehnik pengumpulan data pada penelitian ini adalah wawancara, observasi, dan dokumentasi. Sebab bagi peneliti kualitatif kejadian yang terdapat pada subyek dapat dimengerti maknanya secara baik, dan ketika interaksi dengan subyek melalui wawancara mendalam dan observasi pada tempat, dimana fenomena tersebut berlangsung dan di samping itu untuk melengkapi data diperlukan dokumentasi (tentang bahan-bahan yang ditulis oleh atau tentang subyek).

\section{Hasil dan Pembahasan}

Dalam rangka membentuk karakter peserta didik maka, SDIT KH. Abdurahman Mahmud Mertapada Kulon Cirebon yang memiliki tujuan untuk menumbuhkan pengetahuan dan sikap keagamaan peserta didik guna dipraktekkan dalam kehidupan sehari-hari memiliki metode dalam penanaman nilai-nilai keagamaan anak. Tentunya, metode penanaman nilai-nilai keagamaan pada anak harus sesuai dengan prinsipnya. Adapun prinsip tersebut antara lain adalah: pertama, Prinsip pentingnya keteladanan dari lingkungan dan orang tua / keluarga anak. Karena pendidikan anak pada dasarnya dimulai dan dilaksanakan di lingkungan keluarga maka dari itu, lingkungan keluarga harus menjadi contoh yang baik untuk anaknya. Apa yang disampaikan orang tua kepada anak, ia akan mengingatnya dan mencoba untuk melakukannya. Disamping itu, lingkungan keluarga di sekolah dalam hal ini adalah guru yang berperan sebagai orang tua disekolah harus memiliki keteladanan dalam menanamkan nilai-nilai keagamaan pada anak atau peserta didik.

Kedua, Prinsip psikologi perkembangan anak. Setiap guru seyogyanya menyampaikan materi nilainilai keagamaan yang disesuaikan dengan landasan ilmu psikologi perkembangan peserta didik. Dalam tinjauan ilmu psikologi dikenal adanya tugas-tugas perkembangan maka setiap materi yang akan disampaikan seyogyanya senantiasa dihubungkan dengan prinsip-prinsip dasar psikologi pendidikan.

Dengan berpedoman pada prinsip tersebut penanaman nilai-nilai keagamaan pada anak akan terlaksana dengan baik. peserta didik akan memahaminya dengan cepat dan diharapkan mampu diaplikasikan dalam kehidupan sehari-hari. Selain itu, pelaksanaan penanaman nilai-nilai keagamaan pada anak harus sesuai dengan prinsip, para guru di sekolah seyognya memiliki pendekatan atau metode yang tepat agar penanaman nilai-nilai keagamaan pada anak terlaksana dengan maksimal sehingga peserta didik mmampu mengaplikasikan nilai-nilai keagamaan dalam kehidupan sehari-hari.

Untuk mencapai tujuan dari penanaman nilai-nilai agama Islam yang telah ditentukan, seorang guru dituntut agar cermat memilih dan menetapkan metode apa yang tepat digunakan untuk menyampaikan materi pelajaran pada peserta didik (Armai Arief, 2002:109).

Adapun metode yang digunakan guru SDIT dalam menanamkan nilai-nilai 
keagamaan pada peserta didiknya adalah sebagai berikut:

\section{Mauizhoh Hasanah (Nasehat)}

Menurut Al-Ajami (2006:139-142) ada beberapa hal yang harus diperhatikan oleh para pendidik, orang tua, dan para da'i atau guru dalam memberikan nasehat: pertama, memberi nasehat dengan perasaan cinta dan kelembutan. Nasehat orang-orang yang penuh kelembutan dan kasih sayang mudah diterima dan mampu merubah kehidupan manusia. Kedua, menggunakan gaya bahasa yang halus dan baik. ketiga, pemberi nasehat harus menyesuaikan diri dengan aspek tempat, waktu, dan materi. Keempat, menyampaikan hal-hal yang utama, pokok dan penting.

Pola nasehat akan bejalan baikpada seseorang jika seseorang menasehati juga melaksanakan apa yang dinasehatkan yaitu dibarengi dengan teladan. Bila tersedia teladan yang baik maka nasehat akan berpengaruh terhadap jiwanya dan akan menjadi suatu yang sangat besar manfaatnya dalam pendidikan rohani (Salman Harun, 1993:334).

Metode nasihat pun tertuang dalam AlQur'an yang penuh dengan ayat-ayat yang menjadikan metode nasihat (memberikan pengajaran) sebagai dasar dakwah, jalan menuju perbaikan individu, dan memberi petunjuk kepada berbagai kelompok. Adapun metode nasihat memiliki ciri seperti berikut ini:

a) Menyeru untuk Memberikan Kepuasan dengan Kelembutan atau Penolakan

b) Metode Cerita dengan disertai Tamsil Ibarat dan Nasihat Penasihat yang sadar, pendidik yang bijaksana, dan da'i yang berpengaruh dapat menyampaikan kisah dengan gaya bahasa dan struktur yang sesuai dengan daya tangkap orang-orang.

Dengan alasan tersebut, hendaklah para pendidik berusaha menggugah emosi dan perhatian anak-anak, ketika menyampaikan cerita.

Fungsi pola nasehat adalah untuk menunjukkan kebaikan dan keburukan, karenatidak semua orang bias menangkap nilai kebaikan dan keburukan. Untuk itudiperlukan suatu pengarahan. Oleh karena itu, anak memerlukan nasehat, nasehat yang lembut, halus, tetapi berbekas, yang bisa membuat anak menjadi baik dan tetap berakhlak mulia (Salman Harun, 1993: 335).

Adapun metode nasehat yang dilaksanakan guru dan kepala sekolah kepada peserta didik SDIT Abdurahman Mahmud antara lain:

a. mengajak peserta didik untuk selalu bertaqwa kepada Allah dan semangat dalam belajar. Hal ini biasanya dilakukan pada saat guru mengawali pembelajaran di kelas.

b. bercerita tentang perihal hikmah dalam setiap peristiwa. Pelaksanaanya pada saat jam pembelajaran. Guru menyelipkan kisah para nabi atau para kekasih allah yang selalu diberikan pertolongan. Karena pertolongan Allah akan datang kepada hambanya yang bertaqwa.

c. memberikan nasehat dengan bertutur kata yang lembut dan sopan kepada siapa yang kita jumpai. Dan selalu menebarkan kedamaian antar sesama sauadra dan teman.

\section{Uswatun Hasanah (Keteladanan)}

Keteladanan dalam pendidikan merupakan metode yang berpengaruh dan terbukti paling berhasil dalam mempersiapkan dan membentuk aspek moral, spiritual dan etos anak. Mengingat 
pendidik adalah seorang figur terbaik dalam pandangan anak yang tindak tanduk dan sopan santunnya, disadari atau tidak akan ditiru oleh mereka. Bahkan bentuk perkataan, perbuatan dan tindak tanduknya akan senantiasa tertanam dalam kepribadian anak. Oleh karena itu masalah keteladanan menjadi faktor penting dalam menentukan baik buruknya anak (Nashih Ulwan, 2007: 142).

$\begin{array}{clc}\text { Dalam kamus besar bahasa } & \text { kahwa } \\ \text { Indonesia } & \text { disebutkan } & \text { bahwo }\end{array}$
"Keteladanan"dasar katanya teladan yaitu perbuatan atau barang yang dapat ditiru dan dicontoh (Armai Arief, 2002:117). Keteladanan yang dimaksudkan di sini adalah bagaimana seorang pendidik memberikan contoh terbaik dalam pandangan. Pendidik akan dengan mudahnya ditiru oleh anak didiknya, baik itu berupa tindak-tanduknya, dan tata santunnya dan bahkan mungkin juga cara jalannya. Hal ini disadari ataupun tidak, bahkan tercetak pula dalam jiwa dan perasaan tentang gambaran pendidik tersebut, baik dalam ucapan atau perbuatan.

Masalah keteladanan adalah faktor penting hal baik-buruknya anak. Jika pendidik jujur, dapat dipercaya, berakhlak mulia, berani dan juga menjauhkan diri dari perbuatan yang bertentangan dengan agama, maka si anak akan tumbuh menjadi anak yg jujur pula serta akan terbentuk akhlak mulia.

Berdasarkan pendapat di atas seorang guru hendaklah dalam mendidik dan membimbing peserta didiknya dengan keteladanan yang diberikan oleh gurunya dalam kehidupan sehari-hari, baik guru kelas maupun guru mata pelajaran artinya mereka harus senantiasa memberikan contoh. diantaranya yaitu: a) melaksanakan shalat dzuhur berjama'ah; guru memberikan contoh terhadap peserta didiknya secara baik dan benar. Apabila waktu duhur telah tiba, guru memberikan contoh untuk segera pergi ke masjid guna melaksanakan shalat dzuhur berjama'ah.

b) melaksanakan amalan shalat sunnah (Duha); selain ibadah wajib yang dicontohkan, seorang guru juga harus memberikan contoh dalam ibadah sunnah. Ibadah sunnah yang biasa dicontohkan ialah melaksanakan shalat Duha. Pelaksanaan shalat duha biasannya dikerjakan ketika jam istirahat pertama yaitu jam 09.30 WIB. Guru bergegas menuju masjid untuk melaksanakan shalat duha. Dengan begitu, tidak hanya lewat anjuran untuk shalat duha akan tetapi dicontohkan lewat perbuatan dan tindakan.

c) Penanaman nilai keagamaan pada peserta didik ialah dengan membuang sampah pada tempatnya. Ketika guru melakukan hal tersebut dan diintruksikan kepada peserta didik "Anak-anak kalau buang sampah pada tempatnya yang ada di depan kelas itu yah!", diharapakan peserta didik melakukannya dengan membuang sampah pada temptnya. Karena seperti yang telah kita ketahu bersama bahwa, kebersihan itu sebagian daripada iman

d) Guru (standby and ready) lebih dahulu di depan kelas saat pembacaan Asmaul Husna; kegaiatan dalam rangka menumbuhkan sikap keagamaan peserta didik yaitu dengan rutinitas 
membaca nama-nama Allah yang baik (Asmaul husna). Kegiatan ini dilaksanakan sebelum pembelajaran dimulai.

\section{Attu'udiyyah (Pembiasaan)}

Pembiasaan merupakan proses pembentukan sikap dan perilaku yang relative menetap melalui proses pembelajaran yang berilang-ulang (Wening Wulandaru, 2012: 1). Pembiasaan adalah tingkah laku tertentu yang bersifat otomatis tanpa direncanakan terlebih dahulu dan berlaku begitu saja tanpa dipikirkan lagi. Dengan pembiasaan pendidikan memberikan kesempatan kepada peserta didik terbiasa mengamalkan ajaran agamanya, baik secara individual maupun secara berkelompok dalam kehidupan sehari-hari. Pembiasaan yang dilakukan peserta didik SDIT Abdurahman Mahmud ialah:

a) dengan berinfaq setiap hari sabtu. Peserta didik diajarkan untuk membiasakan berbuat baik dengan menyisihkan uang jajannya guna membantu orang lain yang membutuhkan. Pembiasaan yang lainnya ialah.

b) peserta didik membaca Al-Qur'an (mengaji) sebelum jam pertama dimulai. Pelaksanannya peserta didik mengaji dengan dikelompokkan sesuai tingkatannya. Pembiasaan ini diharapkan agar peserta didik mampu mengaplikasikannya kapanpun dan dimanapun mereka berada untuk senantiasa membaca kalam Ilahi.

c) shalat dzuhur berjama'ah; pembiasaan ini dilakukan agar peserta didik selalu dekat dengan masjid dan menjalankan ibadah shalat lima waktu dengan berjama'ah yaitu ketika mereka berada dirumah.

d) peserta didik senantiasa berdo'a sebelum dan setelah pembelajaran. Dan mengucapkan salam saat datang ke sekolah dan pulang. Dengan pembiasaan ini diharapkan apa yang dipelajari peserta didik di sekolah akan bermanfaat dan mendapat ilmu yang barokah untuk bekal dikehidupannya nanti.

\section{Mulahadzoh Muhasyafah \\ (Pengawasan/Perhatian intensif)}

Pendidikan dengan perhatian adalah senantiasa mencurahkan perhatian penuh dan mengikuti perkembangan aspek akidah dan moral anak, mengawasi dan memperbaiki kesiapan mental dan sosial, disamping selalu bertanya tentang situasi pendidikan jasmani dan kemamuan ilmiahnya (Nashih Ulwan, 2007, 275).

Berdasarkan pendapat di atas bahwa guru hendaklah mendidik dan membimbing peserta didik dengan selalu memperhatikan dan mengawasi perkembangan dalam berbagai aspek agar anak menjadi manusia yang hakiki dan membangun pondasi Islam yang kokoh. Dalam hal ini guru haruslah memperhatikan dan mengawasi perilaku akhlaknya baik akhlak kepada Allah (ibadah) maupun akhlak kepada sesama manusia, agar mereka senantiasa tekun melaksanakan ibadah khususnya shalat dan ibadah-ibadah umum yang lainnya. Seperti yang telah dijelaskan dalam surat AtTahrim ayat 6 :

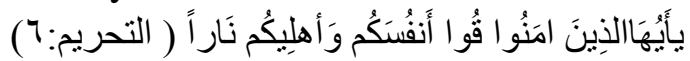

Artinya: Hai orang yang beriman, peliharalah dirimu dan keluargamu dari api neraka. 17

Melalui ayat di atas, maka jelaslah bahwa Allah SWT mewajibkan kepada 
orang tua untuk memperhatikan dan mengawasi keluarganya agar terhindar dari siksa api neraka.

Adapun perhatian yang dilakukan guru dan kepala sekolah SDIT Aburahman Mahmud antara lain:

a) selalu memperhatikan segala tindakan dan perbuatan peserta didiknya baik di sekolah maupun di rumah;

b) guru kelas dan kepala sekolah cepat tanggap dalam segala permasalahan yang dialami peserta didiknya, baik di sekolah maupun di luar sekolah;

c) bukan hanya peserta didiknya yang diperhatikan, kepala sekolah juga selalu mengotrol perilaku dan moral peserta didiknya lewat orangtuanya tatkala berada di rumah dengan berkomunikasi intensif;

d) guru kelas memberikan buku tugas aktiftas keseharian. Melalui buku tersebut, peserta didik untuk mengisinya dengan baik dan jujur. Seperti apakah pada hari itu shalat atau tidak? berjama'ah atau tidak?belajar dan mengaji atau tidak?membantu orang tua atau tidak?. Kemudian, guru akan mengontrol buku tersebut setiap hari sebelum dimulainya pembelajaran.

\section{Ats Tsawaab wa al-'Iqaab (Penghargaan dan Hukuman)}

Menurut Ngalim Purnomo Reward adalah alat untuk mendidik anak-anak supaya anak dapat merasa senang karena perbuatan atau pekerjaannya pekerjaannya mendapat penghargaan (2006:182). Reward merupakan alat pendidikan yang mudah dilaksanakan dan sangat menyenangkan bagi para siswa. Untuk itu, Reward dalam suatu proses pendidikan sangat dibutuhkan kebenarannya demi meningkatkan motivasi belajar siswa. Maksud dari pendidik memberikan Reward kepada siswa adalah supaya siswa menjadi lebih giat lagi usahanya untuk memperbaiki atau mempertinggi prestasi yang telah dicapainya, dengan kata lain siswa menjadi lebih keras kemauannya untuk belajar lebih baik (2006:182).

Peranan Reward dalam proses pengajaran cukup penting terutama sebagai factor aksternal dalam mempengaruhi dan mengarahkan perilaku siswa. Hal ini derdasarkan atas berbagai pertimbangan logis, diantaranya Reward ini dapat menimbulkan motivasi belajar siswa dan dapat mempengaruhi perilaku positif dalam kehidupan siswa.

Manusia selalu mempunyai cita-cita, harapan, dan keinginan. Inilah yang dimanfaatkan oleh metode Reward. Maka dengan metode ini seseorang mengerjakan perbuatan baik atau mencapai suatu prestasi yang tertentu diberikan suatu Reward yang menarik sebagai imbalan (Shomahuddin; 1987:81). Dalam agama islam juga mengenal metode Reward, ini terbukti dengan adanya pahala. Pahala adalah bentuk penghargaan yang diberikan Allah SWT kepada umat manusia yang beriman dan mengerjakan amal-amal shaleh, misalnya: shalat, puasa, membaca Al-quran, dan perbuatan baik lainnya.

SDIT Abdurahman Mahmud dalam menanamkan nilai-nilai keagamaan pada peserta didik dengan metode reward dan punishment. Dengan metode ini,peserta didik akan lebih semangat dalam berlomba-lomba melakukan kebaikan. Adapun metode ini diaplikasikan setiap akhir semester yaitu dengan memberikan penghargaan terhadap peserta didik yang memiliki prestasi unggul dibidang akademik dan memiliki karakter dan sikap sopan santun yang baik selama satu semester. Berbeda dengan peserta didik yang mempunyai karakter kurang baik, mereka 
akan diberikan hukuman. Hukuman yang berkaitan dengan penanaman nilai-nilai keagamaan, yaitu dengan membaca do'a harian dan menghafal surat pendek.

\section{Kesimpulan}

Pendidikan seharusnya tidak hanya mentransfer ilmu dan pengetahuan. Pendidikan harus mampu menjadikan peserta didik mempunyai pengetahuan lebih dan akhlak moral yang baik. Jika pendidikan sebatas pada perubahan kognitif yang jadinya tidak tahu menjadi tahu maka yang akan terjadi dalam kehidupan seharihari ialah peserta didik pintar tanpa diimbangi dengan akhlak yang baik. Untuk itu dalam pendidikan sebaiknya ditanamkan nilai-nilai agama supaya peserta didik pintar dalam pengetahuan dan juga pintar dalam akhlak dan moral. Sehingga peserta didik mampu mempraktekan nilai-nilai keagamaan dalam kehidupan sehari-hari. Berdasarkan hasil pembahasan diatas tentang bagaimana penanaman nilai-nilai keagamaan pada siswa SDIT Abdurahman Mahmud, maka dapat disimpulkan bahwa metode penanaman nilai-nilai keagamaan pada siswa SDIT Abdurahman Mahmud antara lain: Mauizhoh Hasanah (Nasehat), Uswatun Hasanah (Keteladanan), Attu'udiyyah (Pembiasaan), Mulahadzoh Muhasyafah (Pengawasan/Perhatian intensif), dan Ats Tsawaab wa al-'Iqaab (Penghargaan dan Hukuman).

\section{Daftar Pustaka}

Al Munawar, Said Agil Husin. 2005. Fikih Hubungan antar Agama. Jakarta: Ciputat Press.

Badudu-Zain. 1996. Kamus Umum Bahasa Indonesia. Jakarta: Sinar Harapan.

Bogdan dan Taylor. 1975. Metodologi Penelitian Kualitatif. Bandung: Remadja. Karya
Darajat, Zakiah. 1984. Dasar-dasar Agama Islam. Jakarta: Bulan Bintang

Depdiknas. 2008. Kamus Besar Bahasa Indonesia. Gramedia Pustaka.

Harun, Salman. 1993. Sistem Pendidikan Islam. Bandung: Ma-arif

Maimunah, Binti. 2009. Metodologi Pengajaran Agama Islam. Yogyakarta: TERAS

Muhaimin. 2008. Wacana Pengembangan Pendidikan Islam. Yogyakarta: Pustaka Pelajar

Nashih Ulwan, Abdullah. 2008. Pendidikan Dalam Islam. Jakarta: Pustaka Amani

Nursyiam Afifah, metode nasehat dalam Islam", model pembelajaranku, metode belajar, 2014 (online) sumber elektronik diakses dari http://modelpembelajaranku.blogspot.co.id/2014/ 12/metode-nasihat-dalam islam.html, diakses 20 April 2020.

Purwanto, M. Ngalim. 2006. Ilmu Pendidikan Toretis dan Praktis. Bandung: Remaja Rosdakarya.

Shomahuddin, Mahfudh, dkk. 1987. Metodologi Pendidikan Agama. Surabaya: Bina Ilmu

Arief, Armai. 2002. Pengantar Ilmu dan Metodologi Pendidikan Islam. Jakarta: Penerbit Ciputat

Tafsir, Ahmad. 2008. Ilmu Pendidikan dalam Perspektif Islam. Bandung: PT. Remaja Rosdakarya.

W.J.S Poerwadarminta. 1982. Kamus Umum Bahasa Indonesia. Jakarta: Balai Pustaka. 